\title{
POLITYKA BEZPIECZEŃSTWA POLSKI W KONTEKŚCIE GEOPOLITYCZNYCH SKUTKÓW KONFLIKTU NA KRYMIE
}

Przez dwadzieścia pięć lat, które minęły od demokratycznych przemian w Polsce zapoczątkowanych w 1989 r., międzynarodowe środowisko państwa uważane było za stabilne i wolne od bezpośrednich zagrożeń militarnych. Kryzys na Ukrainie i przeprowadzona w pierwszych miesiącach 2014 r. interwencja zbrojna Rosji na Krymie podważyły to przekonanie.

Naruszenie integralności Ukrainy przez Rosję, jako złamanie podstawowych zasad prawa międzynarodowego, winno spotkać się ze zdecydowaną reakcją Organizacji Narodów Zjednoczonych i społeczności międzynarodowej. Szczególnie zobligowane do działania wydają się być jednak Stany Zjednoczone i Wielka Brytania, które - wraz z Rosją - są gwarantami bezpieczeństwa i integralności Ukrainy. Państwa te, na mocy Memorandum budapesztańskiego z 1994 r., w którym Ukraina zdecydowała się przekazać Rosji znajdującą się na jej terytorium strategiczną broń nuklearną, zobowiązały się powstrzymać od użycia siły przeciwko temu państwu oraz bronić jego suwerenności i integralności. Dotrzymanie przez nie złożonych obietnic można traktować jako probierz dotrzymania innych zobowiązań, w tym także tych, które wynikają z układów sojuszniczych.

Międzynarodowe reperkusje zbrojnego konfliktu na Ukrainie mogą więc dotyczyć nie tylko przyszłego statusu Krymu i Ukrainy, ale także wiarygodności NATO, Unii Europejskiej (w tym Wielkiej Brytanii) oraz Stanów Zjednoczonych. W tym kontekście konflikt na Ukrainie może stać się powodem wymuszającym przegląd oraz - być może - redefinicję założeń polskiej polityki bezpieczeństwa. Bezpieczeństwo Polski zostało bowiem oparte na trzech filarach: Sojuszu Północnoatlantyckim, Unii Europejskiej oraz partnerstwie ze Stanami Zjednoczonymi. Spoiwem tych filarów jest przekonanie o dotrzymaniu zobowiązań sojuszniczych przez USA oraz partnerów z UE i NATO. Konflikt zbrojny na Ukrainie może też stać się testem wiarygodności polskiego działania na arenie międzynarodowej, w tym także wewnątrz UE. Konflikt toczy się bowiem nie tylko bezpośrednio za granicą Polski, ale również w strefie unijnego Partnerstwa Wschodniego, w której polskie władze predestynują do pełnienia roli lidera unijnej aktywności, wspierającego demokratyczne przemiany oraz deklarują możliwość użycia polskich sił zbrojnych w ramach misji pokojowych i stabilizacyjnych Unii Europejskiej i NATO.

Osnową polskiej polityki bezpieczeństwa jest obecnie założenie o konieczności budowy spójnego zachodniego systemu bezpieczeństwa, składającego się z komplementarnie działających organizacji: Unii Europejskiej i Sojuszu Północnoatlantyckiego, w którym stabilizującą rolę pełni transatlantycki partner Europy - Stany Zjednoczone. 
Polska opowiada się za zintegrowanym podejściem do kształtowania obrony państw europejskich. Postuluje kompleksowe myślenie o bezpieczeństwie obszaru transatlantyckiego i dążenie do zbudowania efektywnej, militarnej zdolności do działania państw europejskich, wykorzystywanej zarówno w ramach UE, jak i NATO. Z perspektywy polskiego bezpieczeństwa ważne jest zachowanie potencjału polityczno-militarnego NATO i UE i dalsze jego wzmacnianie, w tym sprawne reagowanie na współczesne zagrożenia dla bezpieczeństwa.

Istotny wpływ na współczesną koncepcję działania Polski na arenie międzynarodowej maja jednak nie tylko bieżące wydarzenia, ale i przeszłość państwa. Mimo przemian w polskiej koncepcji bezpieczeństwa, do których doszło w pierwszej dekadzie XXI wieku, wpływ na polską kulturę bezpieczeństwa oraz na kształt interesów bezpieczeństwa państwa zachowują traumatyczne historyczne doświadczenia. Niewywiązanie się Francji i Wielkiej Brytanii ze zobowiązań sojuszniczych i niepodjęcie przez nie nawet próby udzielenia pomocy Polsce zaatakowanej przez III Rzeszę Niemiecką i ZSRR (Francja i Wielka Brytania poprzestały na wypowiedzeniu wojny III Rzeszy) nadal obecne jest w narodowej pamięci historycznej, w której ujmowane jest jako zdrada dokonana przez sojuszników. Tak samo ocenione jest zachowanie dyplomacji państw zachodnich na konferencjach w Jałcie i Poczdamie w 1945 r., kiedy po latach walki po stronie aliantów Polska stała się przedmiotem gry interesów ówczesnych mocarstw, a państwa zachodnie - w imię pragmatyzmu politycznego - „porzuciły Polskę” (Malinowski, 2013: 30) godząc się na jej wejście w orbitę wpływów ZSRR. Odium ,porzucenia sojusznika" nie dotknęło Stanów Zjednoczonych. Co więcej, USA przez okres zimnej wojny postrzegane były jako naturalny sojusznik prodemokratycznej opozycji w Polsce, jako jedyne państwo zdolne do powstrzymania „radzieckich tendencji ekspansywnych" i zablokowania budowy komunizmu w Europie. Markę tę Stany Zjednoczone wzmacniały, udzielając politycznego i materialnego wsparcia prowadzonym w Polsce działaniom antykomunistycznym. Równocześnie militarna obecność USA na kontynencie europejskim została uznana za gwarancję kontroli wzrostu militarnej potęgi Niemiec. Te doświadczenia historyczne wpływają na obecność w narodowej kulturze bezpieczeństwa przekonań o: konieczności tworzenia wielorakich gwarancji dla bezpieczeństwa narodowego, obowiązku dotrzymywania zobowiązań sojuszniczych oraz konieczności budowy multilateralnych porozumień o bezpieczeństwie (jako skuteczniejszych, bardziej efektywnych i wiarygodnych aniżeli porozumienia dwustronne) oraz obaw: przed byciem przedmiotem umowy między innymi państwami (i wynikającym z tego silnym dążeniem do zachowania wpływu na kształt europejskiej i transatlantyckiej kultury bezpieczeństwa i na procesy bezpieczeństwa prowadzone na kontynencie); przed zwycięstwem partykularnych interesów narodowych państw nad wspólnymi interesami wspólnoty, co oznaczałoby naruszenie zasady solidarności członków wspólnoty; przed zgodą na tworzenie przez mocarstwa i supermocarstwa stref wpływów (głównie obawy przed uznaniem przez państwa Europy Zachodu obszaru Europy Wschodniej jako strefy wpływów Rosji) i przed powrotem Rosji do polityki mocarstwowej. W kulturze bezpieczeństwa zakorzeniony jest także silny proamerykanizm, który w ostatnich latach uległ jednak osłabieniu.

Od zakończenia II wojny światowej główne założenia polityki bezpieczeństwa Polski ulegały rewolucyjnym przemianom. Ostatnia zmiana wektora narodowej polityki 
bezpieczeństwa, dokonana po rozwiązaniu wschodnich struktur integracyjnych i rozpadzie ZSRR, doprowadziła do wprowadzenia Polski do wspólnoty państw zachodnioeuropejskich. Przez dekadę lat 90. XX w., po rozwiązaniu Organizacji Układu Warszawskiego, Polska, podobnie jak inne państwa regionu, nie będąc związanymi żadnymi sojuszami pozostawała w próżni bezpieczeństwa. W tym czasie zdecydowano więc o uruchomieniu mechanizmów stabilizowania i wzmacniania bezpieczeństwa w wielu wymiarach (m.in. politycznym, militarnym i gospodarczym) i z użyciem maksymalnej liczby instytucji. Starano się także postrzegać konieczność budowy bezpieczeństwa międzynarodowego we wszystkich skalach: lokalnej, regionalnej i globalnej.

Główne metody zapewniania bezpieczeństwa zostały określone przez pierwszy wolnościowy rząd Tadeusza Mazowieckiego (istotny wpływ na nie miał minister spraw zagranicznych Krzysztof Skubiszewski) i obejmowały: integrację z zachodnimi strukturami politycznymi, militarnymi i gospodarczymi, tworzenie regionalnych porozumień i lokalnych inicjatyw na rzecz stabilizowania bezpieczeństwa oraz uregulowanie stosunków z państwami sąsiedzkimi. W ciagu półtorej dekady kolejnym polskim rządom udało się osiagnąć cele uznawane przez zachodnich partnerów w 1991 r. za nierealne (państwa NATO i Wspólnoty Europejskiej postulowały na początku lat 90. XX w. utworzenie z obszaru Europy Środkowej i Wschodniej strefy buforowej między zachodnim aliansem a Rosją, posiadającej krzyżowe - zachodnie i rosyjskie - gwarancje bezpieczeństwa): w 1999 r. Polska stała się członkiem Sojuszu Północnoatlantyckiego (członkostwo to zostało poprzedzone uczestnictwem od 1994 r. w programie Partnerstwo dla Pokoju), a w 2004 r. Unii Europejskiej. Do roku 1994 uregulowano kwestię granic i podpisano ze wszystkimi siedmioma państwami sąsiedzkimi Układy o dobrym sąsiedztwie i współpracy. Polska podjęła również współdziałanie w porozumieniach regionalnych w ramach Trójkąta Weimarskiego, Inicjatywy Środkowoeuropejskiej, Grupy Wyszehradzkiej i Rady Państw Morza Baltyckiego. W związku z doświadczeniami historycznymi polskie rządy starały się przede wszystkim wzmacniać zdolność obrony przed zagrożeniami, których źródło było zewnętrzne.

Podstawowym powodem dążenia Polski do integracji z zachodnimi strukturami była chęć zapewnienia gwarancji nienaruszalności terytorium i obrony suwerenności państwa. Z tego powodu kolejne rządy od początku członkostwa w NATO opowiadały się przede wszystkim za umacnianiem zobowiązań, które leżały u podstaw powołania Sojuszu i lobbowały za zwiększaniem zdolności do obrony terytorium państw członkowskich. Podobnie jak pozostałe państwa regionu Europy Środkowej i Wschodniej optowały za ograniczaniem prowadzonych przez NATO akcji out of area. Strategia Bezpieczeństwa Narodowego Rzeczypospolitej Polskiej z 2007 r. stanowi że: „W polskim interesie leży, aby Sojusz Północnoatlantycki pozostał instrumentem zbiorowej obrony państw członkowskich, adaptując jednocześnie swe zdolności cywilne i wojskowe do zwalczania nowych zagrożeń [...] Sojusz Północnoatlantycki jest dla Polski najważniejszą formą współpracy wielostronnej w polityczno-wojskowym wymiarze bezpieczeństwa oraz filarem stabilności na kontynencie, a także główną płaszczyzną stosunków transatlantyckich" (Strategia, 2007: 7, 11).

W momencie przystąienia do zachodnich struktur integracyjnych Polska postrzegała NATO jako głównego gwaranta bezpieczeństwa. Unię Europejską traktowano 
jako mniej znaczącą w stanowieniu gwarancji w tradycyjnych wymiarach bezpieczeństwa (politycznym i militarnym). Wraz z intensyfikacją rozwoju unijnej Wspólnej Polityki Zagranicznej i Bezpieczeństwa, a następnie Wspólnej Polityki Bezpieczeństwa i Obrony oraz równolegle do zmian zachodzących na arenie międzynarodowej Polska zaczęła dostrzegać potencjalnie znaczącą rolę unijnych gwarancji bezpieczeństwa. Proces ten wzmocniło przyjęcie przez państwa członkowskie UE Traktatu z Lizbony, którego art. 42.7 wprowadził gwarancje sojuszniczej obrony.

Stosunek Polski do Wspólnej Polityki Bezpieczeństwa i Obrony na przestrzeni ostatnich lat znacząco się jednak zmienił. Przed przystapieniem do Unii Europejskiej i w pierwszych latach członkostwa Polska niezwykle sceptycznie podchodziła do koncepcji rozwoju wspólnej europejskiej obrony, przedstawianej jako alternatywny względem NATO sposób zapewniania bezpieczeństwa w regionie. Opowiadała się raczej za proponowaną w ramach Sojuszu Północnoatlantyckiego Europejskq Tożsamościa Bezpieczeństwa i Obrony (ang. European Security and Defence Indentity - ESDI). Propozycje tworzenia wspólnego systemu bezpieczeństwa państw UE zawarte w Traktacie z Maastricht z 1993 r., zaprojektowane w Traktacie z Amsterdamu z 1997 r. i ukonkretnione w deklaracjach z Kolonii z 1999 r., Helsinek z 1999 r. i Feiry z 2000 r. postrzegane były jako zagrożenie dla spójności wspólnoty transatlantyckiej i nie znajdowały poparcia. Polacy negowali pomysł tworzenia równoległych do NATO struktur wojskowych i budowy w Unii Europejskiej niezależnej wojskowej zdolności do działania. Traktowali je jako próbę zminimalizowania amerykańskiego zaangażowania na kontynencie europejskim, co uważali za niezgodne z narodową racją stanu.

W czasie negocjacji akcesyjnych z Unią Europejską rząd polski, zobligowany do zaaprobowania wypracowanych przez unijne państwa założeń Wspólnej Polityki Zagranicznej i Bezpieczeństwa (ang. Common Foreign and Security Policy-CFSP), formalnie uznał regulacje dotyczące $C F S P$, pozostał jednak wobec nich sceptyczny. Aprobowano prowadzenie przez UE misji zarządzania kryzysowego, jednak starano się nie odnosić do ogólnego zamiaru tej polityki, czyli budowy alternatywnego wobec systemu transatlantyckiego systemu bezpieczeństwa europejskiego. W 2000 r. do polskiej Strategii Bezpieczeństwa Narodowego wpisano włączenie państwa w polityczne i wojskowe struktury unijne, jednak nie zmieniło to polskiej optyki. Podczas wdrażania przez Unię postanowień traktatu z Nicei z 2001 r. i unijno-natowskich negocjacji o wykorzystywaniu zasobów NATO podczas operacji prowadzonych przez Unię Europejską Polska - podobnie jak Turcja - odnosiła się do tego pomysłu niechętnie. Choć Polska wsparła realizację pierwszej unijnej misji realizowanej w ramach CSDP (Concordia w byłej Jugosłowiańskiej Republice Macedonii - FYROM), jednak nie oznaczało to pełnej akceptacji dla unijnej Wspólnej Polityki Bezpieczeństwa i Obrony, ale było wyrazem polskiej woli solidarnego działania z unijnymi partnerami. W trakcie prac nad traktatem wprowadzającym tzw. Konstytucję dla Europy (podpisanym w 2004 r.) przedstawiciele Polski, zgodnie z ówczesnymi założeniami bezpieczeństwa państwa, opowiadali się za oddaniem prymatu w kształtowaniu obrony europejskich państw Sojuszowi Północnoatlantyckiemu, a nie Unii Europejskiej. Na zmianę tego stanowiska nie wywarły wpływu nowe regulacje dotyczące CSDP zawarte w Konstytucji dla Europy (nawet klauzule sojusznicza i solidarności, pożądane z perspektywy polskiej racji stanu), ani początkowo zapisy Traktatu z Lizbony z 2007 r. 
Dopiero wydarzenia na arenie międzynarodowej zachodzące równolegle do postępującej ewolucji koncepcji CSDP (szczególnie kryzysy na obszarze unijnej bliskiej zagranicy - na Kaukazie w 2008 r., a później także na Bliskim Wschodzie i w Maghrebie) oraz przewartościowanie priorytetów amerykańskiej polityki zagranicznej doprowadziły do zmian w postrzeganiu przez Polskę Wspólnej Polityki Bezpieczeństwa i Obrony UE oraz pojawienia się politycznej woli korzystania z jej rozwiązań. Nie bez znaczenia dla reorientacji polityki była zmiana u steru rządów w Polsce. Nowy rząd zaczął aktywnie włączać się w budowę europejskiej zdolności do stabilizowania bezpieczeństwa i wzmacniania obrony, dążąc wręcz do przejęcia wiodącej roli w jej kształtowaniu. Polska dyplomacja wsparła francuskie wysiłki na rzecz efektywnej reformy CSDP i wraz z Niemcami, działając w ramach Trójkata Weimarskiego, w $2010 \mathrm{r}$. zaapelowała do Catherine Ashton, Wysokiej Przedstawiciel UE ds. Polityki Zagranicznej i Bezpieczeństwa o zwiększenie efektywności implementacji postanowień Traktatu lizbońskiego. Wzmocnienie efektywności CSDP stało się też jednym z zadań wyznaczonych do realizacji przez Polską Prezydencję w drugiej połowie 2011 r. W kolejnym roku polska dyplomacja rozpoczęła prace na rzecz wzmocnienia CSDP w partnerstwie z Francją i Niemcami (w ramach Trójkąta Weimarskiego), uznając, że „Wspólnej Polityki Bezpieczeństwa i Obrony Unii Europejskiej nie daje się niestety realizować w 27 państw i należy zainicjować przewidzianą w Traktacie z Lizbony wzmocnioną współpracę państw chętnych" (Exposé, 2012). Od 15 grudnia 2012 r. do współpracy tej dołączyły Włochy i Hiszpania, tworząc strukturę nazwaną Weimar Plus.

Nie bez znaczenia dla dokonanej przez Polskę oceny roli NATO i UE w zapewnianiu bezpieczeństwa europejskiego stała się zmiana oceny amerykańskiego zaangażowania na świecie. W okresie zimnowojennym i podczas pierwszej dekady po tranzycji systemowej Polska uważała militarną obecność Stanów Zjednoczonych w Europie za gwarancję stabilności, a partnerstwo transatlantyckie za niezbędny element konstytuujący bezpieczeństwo państw europejskich. Zmiany w polityce USA dokonane po ataku terrorystycznym z 11 września 2001 r., w tym przeniesienie ciężaru amerykańskiego zaangażowania na obszar Bliskiego i Środkowego Wschodu oraz Azji i Pacyfiku, doprowadziły w Polsce do konstatacji, że aktywność amerykańska w obecnie priorytetowych dla USA regionach może pochłonąć tak dużą część ich zdolności do działania i woli międzynarodowego zaangażowania, że kiedy państwa europejskie (w tym Polska) znajdą się w sytuacji zagrożenia mogą nie otrzymać pomocy zgodnej ze swoimi oczekiwaniami (Exposé, 2011). Równocześnie zauważono też, że rozpoczęta przez USA ,wojna z terroryzmem” doprowadziła do kooperacji z Rosja, co polska dyplomacja oceniała sceptycznie (szczególnie w pierwszych latach XXI w.) i w czym upatrywała zagrożenia oddania obszaru postradzieckiego pod rosyjską ,,antyterrorystyczną” kuratelę. Obawiano się też długofalowych skutków większego niż słuszne - z polskiego punktu widzenia - uwzględniania opinii rosyjskiej dyplomacji podczas wewnątrznatowskich debat o bezpieczeństwie. Także dokonana przez USA w ramach walki z terroryzmem interwencja zbrojna w Iraku, choć wsparta przez Polskę, doprowadziła do przewartościowań w polskiej polityce. Podział w łonie wspólnoty transatlantyckiej, spowodowany interwencją i niemiecko-francuską negacją tego działania, unaocznił polskiej dyplomacji rozbieżność interesów partnerów z obu stron Atlantyku i został zinterpretowany jako zagrożenie dla - ważnej dla Polski - sojuszniczej spójności. To 
właśnie ta „sojusznicza spójność” i „dotrzymywanie zobowiązań sojuszniczych” wobec USA były głównym powodem polskiego zaangażowania w Iraku. Te same powody podawano podczas wspierania pomysłu budowy tarczy antyrakietowej w Europie. Zmiana polityki zagranicznej USA, dokonana przez Baracka Obamę, w tym polepszenie stosunków z Francją i Niemcami oraz rezygnacja z budowy tarczy stały się jednak impulsem do rozważań nad istotą związków sojuszniczych.

Konstatacje z ostatnich lat wpłynęły znacząco na postrzeganie przez Polskę roli NATO, Unii Europejskiej i USA, ich wagi dla polskich interesów bezpieczeństwa oraz skali pożądanego polskiego udziału w działaniach podejmowanych przez te podmioty. Od 2012 r. aktywna partycypacja w NATO (jako głównym gwarancie obrony terytorialnej), rozwijanie zdolności UE do efektywnej obrony i reagowania kryzysowego wraz ze strategicznym partnerstwem ze Stanami Zjednoczonymi (USA zgodnie z oceną polskiego rządu ,pozostaną w najbliższych latach kluczowym aktorem w dziedzinie bezpieczeństwa międzynarodowego") - stanowią trzy filary bezpieczeństwa Polski (Priorytety, 2012:14). Według Polski NATO i Unia Europejska mogą być wobec siebie komplementarne w dziedzinie obronności. NATO winno skupić się na obronie terytorium państw członkowskich i realizacji misji stabilizacyjnych, a Unia Europejska na przeprowadzaniu misji kryzysowych w sąsiedztwie Europy, przy zachowaniu jednak unijnej zdolności do obrony terytorium państw członkowskich. W przyjętej przez rząd w 2013 r. Strategii Rozwoju Systemu Bezpieczeństwa Narodowego do roku 2022 Polska jako realizację celu „kształtowanie stabilnego międzynarodowego środowiska bezpieczeństwa w wymiarze regionalnym i globalnym” postawiła: „wzmacniać kolektywną obronę w ramach NATO” oraz „rozwijać zdolności UE do prowadzenia kompleksowych działań w zakresie reagowania kryzysowego" (Strategia, 2013: 39-42). Ograniczeniem dla polskiej aktywności w tym zakresie mogą być w najbliższych latach kwestie finansowe. Zgodnie z Priorytetami polskiej polityki zagranicznej na lata 2012-2016: „Polska, utrzymująca przez najbliższe lata wydatki na poziomie 1,95\% PKB, winna być w NATO i UE adwokatem zachowania potencjału obronnego w Europie" (Priorytety, 2012: 14). Z tego też powodu władze polskie opowiadają się za rozwijaniem sił podwójnego zastosowania, zdolnych zapewniać skuteczną obronę terytorium państwa i prowadzić akcje reagowania kryzysowego.

Polska dostrzega konieczność reagowania kryzysowego, jednak różnicuje dopuszczalny sposób własnego zaangażowania dokonując hierarchizacji regionów kryzysowych oraz - pod względem ważności - szeregując organizacje prowadzące misje reagowania kryzysowego oraz misje stabilizacyjne. Obszarem, na którym rząd polski dopuszcza prowadzenie działań antykryzysowych jest region bliskiej zagranicy UE. Polska jednak dzieli go na dwie strefy. W państwach Partnerstwa Śródziemnomorskiego dopuszcza swój udział w misjach cywilnych i koncentruje się głównie na wspieraniu demokracji, poszanowania dla praw człowieka i promowaniu pozytywnych wzorców tranzycji systemowej. Spośród operacji wojskowych realizowanych w tym regionie dopuszcza jedynie wysyłanie oddziałów wspierających główne siły sojuszników, co można uznać za realizację istotnej dla Polski zasady dotrzymywania zobowiązań sojuszniczych. Szersze zaangażowanie - polityczne i wojskowe - dopuszcza w państwach należących do Partnerstwa Wschodniego oraz na Bałkanach i w Afganistanie, gdzie zakłada możliwość wykorzystywanie pełnego katalogu działań pozo- 
stających do dyspozycji władz państwowych, zarówno cywilnych, jak i wojskowych (ibidem).

Zgodnie z uregulowaniami formalnoprawnymi polskie siły zbrojne mogą być używane poza granicami państwa w celu obrony kraju oraz państw sojuszniczych ${ }^{1}$ oraz w celu stabilizacji obszarów kryzysowych w ramach operacji reagowania kryzysowego i operacji antyterrorystycznych prowadzonych przez NATO, UE, OBWE, ONZ i koalicje chętnych państw. Jednakże wobec niemocy zaangażowania pokojowego i stabilizacyjnego na wszystkich obszarach kryzysowych, na których ONZ, NATO i UE prowadziły misje wojskowe i cywilne, polskie władze dokonały oceny użyteczności misji pokojowych poszczególnych organizacji dla realizacji polskich interesów narodowych. W konsekwencji zhierarchizowano misje poszczególnych organizacji. Za nadrzędne dla interesów państwa uznano misje Sojuszu Północnoatlantyckiego i Unii Europejskiej, kolejne miejsce zajęy misje prowadzone pod sztandarem ONZ, a na dalszej pozycji ulokowano głównie obserwacyjne misje OBWE. Osobną kategorię, zależną tylko od bieżącej woli politycznej stanowiły misje stabilizacyjne, realizowane w celu dotrzymania zobowiązań sojuszniczych. Gradacja misji pokojowych okazała się być decydującą podczas określania miejsc dyslokacji polskich oddziałów wojskowych poza granicami w ostatniej dekadzie.

Użycie sił zbrojnych poza granicami dopuszczalne jest zarówno w formie długotrwałej (z rotacyjną zmianą oddziałów), jak i krótkotrwałej (bez rotacji), zależnie od potrzeb. Pobyt żołnierzy poza granicami regulują szczegółowo akty prawa wewnętrznego. Podstawę prawną pobytu i użycia polskich sił zbrojnych poza granicami stanowi Ustawa o zasadach użycia lub pobytu sił zbrojnych poza granicami państwa z $1998 \mathrm{r}$. Zgodnie z jej regulacjami o użyciu sił zbrojnych poza terytorium Polski w konflikcie zbrojnym, akcji sojuszniczej, operacji pokojowej lub operacji antyterrorystycznej decyduje prezydent państwa, który podejmuje działanie na wniosek rządu (w trzech pierwszych przypadkach) lub premiera (w ostatnim). O pobycie sił zbrojnych za granicą w celu prowadzenia akcji ratowniczej, poszukiwawczej lub humanitarnej decyduje właściwy minister, sprawujący nadzór nad jednostkami, które mają wziąć udział w operacji (minister spraw wewnętrznych lub minister obrony). Zgoda na użycie lub pobyt sił zbrojnych musi szczegółowo określać: rodzaj wysyłanych jednostek wojskowych i ich liczebność; cel, zakres zadań, obszar działania i czas pozostawiania poza granicami państwa; uzbrojenie i sprzęt wojskowy; system dowodzenia i miejsce w międzynarodowych strukturach (jeśli siły wysyłane są wraz z kontyngentami innymi państw), organy państwa odpowiedzialne za ich pobyt oraz trasy i czas przemieszczania się sił zbrojnych (Ustawa, 1998). Polskie Ministerstwo Obrony Narodowej dopuszcza udział w operacjach niezwiązanych z obroną terytorium państw członkowskich (out of area): tworzenia pokoju (peacemaking), zapobiegania konfliktom (conflict prevention), utrzymania pokoju (peacekeeping), budowania pokoju (peacebuilding), wymuszania pokoju (peace enforcement), humanitarnych (humanitarian relief), wspierających operacje humanitarne (support to humanitarian operations), wspierających

${ }^{1}$ Polska wykonuje wtedy zobowiązania stanowione art. 5 Traktatu waszyngtońskiego i art. 42.7 Traktatu z Lizbony. 
operacje niesienia pomocy ofiarom katastrof (support to disaster relief), poszukiwawczo-ratowniczych (search and rescue), wsparcia ewakuacji ludności cywilnej (support to non-combatant evacuation operations), uwalniania zakładników (extraction operations), pomocy wojskowej władzom cywilnym (military aid/support to civil authorities), egzekwowania sankcji i embargo (enforcement of sanctions and embargoes). MON przewiduje także udział w operacjach prowadzonych w celu walki z terroryzmem: prewencyjnych (anti terrorism), likwidacji skutków ataków terrorystycznych (consequence management), przeciwterrorystycznych - czynnego zwalczania (counter terrorism) (Strategiczne, 2011: 87-88).

Pomimo uczestnictwa w 1999 r. w nieautoryzowanej przez Radę Bezpieczeństwa interwencji humanitarnej w Kosowie późniejsze nadużycie prawa do interwencji zbrojnej w 2001 r. (Afganistan) i 2003 r. (Irak) spowodowało, także w Polsce, ograniczenie poparcia dla interwencji zbrojnych prowadzonych bez zgody Rady Bezpieczeństwa ONZ. Po światowym szczycie głów państw i rządów w 2005 r., na którym ograniczono wcześniej postulowane przez International Commission on Intervention and State Sovereignty prawo wykonywania - w zastępstwie państw - obowiązku ochrony obywateli przed przemocą (Responsibility to Protect) tylko do działań prowadzonych za zgodą Rady Bezpieczeństwa ONZ. Polska zaakceptowała to ograniczenie. W Strategii Bezpieczeństwa Narodowego z 2007 r. zadeklarowano poparcie dla rozwoju koncepcji Responsibility to Protect, w tym podjęcie wysiłków w celu ,adaptacji ONZ do zmieniających się realiów międzynarodowych", ale uznano jednocześnie konieczność uzyskania autoryzacji Rady Bezpieczeństwa ONZ dla każdej akcji wymuszenia pokoju (Strategia, 2007: 14). Pozostaje kwestią otwartą czy kryzys toczący się w bezpośredniej bliskości polskich granic może skłonić władze polskie do redefinicji przyjętego założenia i powrotu do koncepcji zastępczej wobec Rady Bezpieczeństwa ONZ legitymizacji działań z kategorii peace-enforcement, wydawanej przez Zgromadzenie Ogólne ONZ lub właściwe organy organizacji regionalnych. Obecnie obowiązująca koncepcja dotycząca międzynarodowej współpracy militarnej bazuje na prawie, traktatach i zasadach międzynarodowych zarówno w ramach akcji ONZ, jaki też NATO i Unii Europejskiej. W ramach NATO Polska dodatkowo przykłada szczególną wagę do spójnego działania wszystkich sojuszników, natomiast w ramach Unii Europejskiej dopuszcza - zgodnie z regułami Traktatu z Lizbony - kooperację między wybranymi państwami chętnymi umacniać Wspólna Politykę Bezpieczeństwa i Obrony.

Kryzys ukraiński potwierdził wyrażaną przez polski rząd wolę angażowania się na obszarze Partnerstwa Wschodniego i współdziałania z głównymi partnerami Polski w UE - Niemcami i Francją. Konflikt na Krymie i jego przypuszczalne reperkusje jawią się jako jedno z największych wyzwań dla procesów bezpieczeństwa zachodzących na obszarze transatlantyckim od zakończenia zimnej wojny i jednocześnie znaczący test dla założeń polskiej polityki bezpieczeństwa. Rosyjska interwencja na Krymie jest bowiem urzeczywistnieniem obaw przenikających polską kulturę bezpieczeństwa. W przededniu zaplanowanego przez nowe krymskie władze referendum w sprawie irredenty Krymu, które zostało zaplanowane na 15 marca 2014 r., wciąż rodzi się jednak więcej pytań niż można udzielić odpowiedzi. Do najważniejszych - w kontekście polskiej polityki bezpieczeństwa - wydają się należeć pytania: czy wydarzenia na Ukrainie, podobnie jak wojna gruzińsko-rosyjska w 2008 r. i rewolucje 
w państwach arabskich rozpoczęte w $2011 \mathrm{r}$. będą stanowiły impuls do pogłębienia integracji Polski z Unią Europejską, w celu dalszego zwiększenia wspólnoty interesów Polski i pozostałych państw członkowskich UE i w ten sposób zwiększenia prawdopodobieństwa wypełnienia przez sojuszników z UE (i NATO) zobowiązań sojuszniczych w sytuacji, gdy polskie bezpieczeństwo zostanie zagrożone? Czy wiara w pomoc, która zostanie udzielona Polsce przez Stany Zjednoczone, stanowiąca element polskiej kultury bezpieczeństwa, podczas kryzysu krymskiego ulegnie dalszemu osłabieniu? Istotne wydają się także pytania: czy państwa Trójkąta Weimarskiego (i inicjatywy Weimar Plus) będą liderami kształtującymi Wspólnq Politykę Bezpieczeństwa i Obrony UE? Czy polskiej dyplomacji starczy sił, środków i kompetencji by odpowiedzieć na wyzwania związane z konfliktem krymskim zgodnie z deklaracjami, które towarzyszyły proklamowaniu Partnerstwa Wschodniego? Czy polskie władze będą zdecydowane użyć wszystkich środków pozostających do ich dyspozycji? Do tej serii pytań można dołożyć jeszcze kolejne kwestie pozostające obecnie bez odpowiedzi, a posiadające możliwe rozstrzygające znaczenie dla polskiej polityki bezpieczeństwa dotyczące m.in. roli w regulacji i rozwiązaniu kryzysu Wielkiej Brytanii i Stanów Zjednoczonych (gwarantów bezpieczeństwa Ukrainy), spójności i efektywności działania państw członkowskich Unii Europejskiej oraz unijnej dyplomacji, roli Sojuszu Północnoatlantyckiego, a także kształtu przyszłej rosyjskiej polityki zagranicznej i bezpieczeństwa. Zdecydowanie jednak można uznać, że sposób rozstrzygnięcia konfliktu na Krymie wyznaczy nowe punkty odniesienia dla procesów bezpieczeństwa w regionie euroatlantyckim i tym samym wymusi co najmniej korekty polityk bezpieczeństwa państw leżących w tym regionie.

\section{Bibliografia}

Malinowski K. (2013), The Culture of National Security and the Transformation in Polish Security Policy, in: Poland's Security, (eds.) S. Wojciechowski, A. Potyrała, Berlin.

Ministrowie Obrony Grupy Wszehradzkiej (2012), informacja dla mediów, 4.05.2012.

Joint Communiqué of the Ministers of Defence of the Visegrad Group, Litoměrice, http://www.mon.gov.pl/artykul/12818, 15.03.2014.

Strategiczny Przeglad Obrony. Profesjonalne Sity Zbrojne RP w nowoczesnym państwie (2011), Ministerstwo Obrony Narodowej RP, Warszawa.

Exposé Ministra Spraw Zagranicznych RP Radosława Sikorskiego (2011), Ministerstwo Spraw Zagranicznych RP, http://www.msz.gov.pl/pl/polityka_zagraniczna/priorytety_polityki_zagr_2012_2016/expose2/expose2011/, 15.03.2014.

Priorytety Polskiej Polityki Zagranicznej 2012-2016 (2012), Rada Ministrów RP, Warszawa.

Strategia Bezpieczeństwa Narodowego RP (2007), Rada Ministrów RP, Warszawa.

Strategia Rozwoju Systemu Bezpieczeństwa Narodowego RP 2022 (2013), Rada Ministrów RP, Warszawa.

National Visions of EU Defence Policy. Common Denominators and Misunderstandings (2013), (eds.) F. Santopinto, M. Price, Brussels.

Ustawa o zasadach użycia lub pobytu sił zbrojnych poza granicami państwa z dnia 17 grudnia 1998 r. (1998), Dz. U., nr 162, poz. 1117, z późniejszymi zmianami. 


\title{
STRESZCZENIE
}

Przez dwadzieścia pięć lat międzynarodowe środowisko Polski uważane było za stabilne i wolne od bezpośrednich zagrożeń militarnych. Kryzys na Ukrainie i interwencja zbrojna Rosji na Krymie podważyły to przekonanie. Naruszenie integralności Ukrainy przez Rosję winno spotkać się ze zdecydowaną reakcją społeczności międzynarodowej. Szczególnie zobligowane do działania wydają się być jednak Stany Zjednoczone i Wielka Brytania, które - wraz z Rosją - są od 1994 r. gwarantami bezpieczeństwa, integralności terytorialnej i niezależności Ukrainy. Dotrzymanie przez nie złożonych obietnic można traktować jako probierz dotrzymania innych zobowiązań, w tym także tych, które wynikają z układów sojuszniczych. Międzynarodowe reperkusje zbrojnego konfliktu na Ukrainie mogą więc dotyczyć nie tylko przyszłego statusu Krymu i Ukrainy, ale także wiarygodności NATO, Unii Europejskiej (w tym Wielkiej Brytanii) oraz Stanów Zjednoczonych. W tym kontekście konflikt na Ukrainie może stać się powodem wymuszającym przegląd oraz - być może - redefinicję założeń polskiej polityki bezpieczeństwa. Bezpieczeństwo Polski zostało bowiem oparte na trzech filarach: członkostwie w NATO oraz Unii Europejskiej i partnerstwie ze Stanami Zjednoczonymi. Spoiwem tych filarów jest przekonanie o dotrzymaniu zobowiązań sojuszniczych przez USA oraz partnerów z UE i NATO. Artykuł traktuje o ewolucji polskiej polityki bezpieczeństwa. Autorka skupia się na ocenie wagi przykładanej przez Polskę do związków sojuszniczych z NATO, Unią Europejską i Stanami Zjednoczonymi i zastanawia się nad wpływem, jaki mogą na nie wywrzeć naruszenie integralności terytorialnej Ukrainy przez Rosję oraz reakcja głównych aktorów stosunków międzynarodowych regionu euroatlantyckiego na ten fakt.

\section{POLAND'S SECURITY POLICY AND THE GEOPOLITICAL CONSEQUENCES OF THE CRIMEAN CONFLICT}

\begin{abstract}
For twenty-five years Poland's international environment had been considered stable and free from direct military threats. The crisis in Ukraine and Russia's military intervention in the Crimea undermined this belief. Russia's violation of the Ukrainian integrity should meet with an overwhelming response of the international community, especially United States and United Kingdom, who are - together with Russia - the guarantors of Ukraine's security, territorial integrity and independence. The fulfillment of promises US and UK were given to Ukraine could be nowadays regarded as a test, which can assess ability to meet other obligations given by these two states, including those arising from allied systems. International repercussions of armed conflict in Ukraine may therefore affect not only the future status of Crimea and Ukraine, but also the credibility of the North Atlantic Treaty Organization, the European Union (including the UK) and the United States. In this context the conflict in Ukraine can become a reason for forcing the review and possibly redefinition of the assumptions of Poland's security policy. That is because security of Poland was based on three pillars: the NATO and EU membership, and the partnership with the United States. The binder of these pillars is the convince of keeping alliance commitment by the U.S. and partners from EU and NATO. The article discusses the evolution of Poland's security policy. The article focuses on assessing the weight given by Poland to the compounds allied with NATO, the European Union and the United States and asks how the violation of the Ukrainian territorial integrity and the response to this delict given by the main actors of transatlantic relations can influence on Poland's security policy.
\end{abstract}

